\title{
The effects of sesame oil and different doses of estradiol on testicular structure, sperm parameters, and chromatin integrity in old mice
}

\author{
Masoomeh Mohammadzadeh ${ }^{1}$, Majid Pourentezari ${ }^{2}$, Hadi Zare-Zardini ${ }^{3,4,5}$, Ali Nabi ${ }^{1}$, Saeed Ghasemi Esmailabad', \\ Ali Khodadadian ${ }^{6}$, Ali Reza Talebi ${ }^{1}$ \\ 'Department of Reproductive Biology, Yazd Reproductive Sciences Institute, Research and Clinical Center for Infertility, ${ }^{2}$ Department of \\ Biology and Anatomical Sciences, and ${ }^{3}$ Hematology and Oncology Research Center, Shahid Sadoughi University of Medical Sciences, Yazd; \\ ${ }^{4}$ Department of Sciences, Farhangian University, Isfahan; ${ }^{5}$ Medical Nanotechnology and Tissue Engineering Research Center, Yazd Reproductive \\ Sciences Institute and ${ }^{6}$ Department of Medical Genetics, Faculty of Medicine, Shahid Sadoughi University of Medical Sciences, Yazd, Iran
}

Objective: Studies of the effects of estrogens on the male reproductive system have emphasized the role of these hormones in male fertility. Sesame oil has many phytoestrogenic compounds and may improve male fertility. This study investigated the effects of sesame oil and different concentrations of estrogen on sperm parameters and DNA integrity in male mice.

Methods: Twenty old NMRI (The Naval Medical Research Institute) male mice (40 weeks; weight, 30-35 g) were treated with sesame oil or different concentrations of estrogen (estradiol, 1 and $10 \mu \mathrm{L} / \mathrm{kg} /$ day) or received no treatment (controls). After 35 days, sperm parameters and DNA integrity were assessed and analyzed.

Results: Sperm count, progressive motility, and morphology were decreased in the group that received $10 \mu \mathrm{L} / \mathrm{kg}$ of estradiol. A remarkably lower percentage of DNA fragmentation and protamine deficiency were detected in the group that received $1 \mu \mathrm{L} / \mathrm{kg}$ of estradiol. In the groups that received sesame oil and $1 \mu \mathrm{L} / \mathrm{kg}$ of estradiol, the numbers of spermatogonia and Leydig cells were higher than in controls. The combination of sesame oil and $1 \mu \mathrm{L} / \mathrm{kg}$ of estradiol led to improved sperm parameters and chromatin and testicular structure.

Conclusion: Based on this study, consumption of sesame oil and a low concentration of estradiol may improve testicular function in older mice.

Keywords: Chromatin; DNA fragmentation; Estradiol; Gene expression; Sesame oil; Testis

Received: January 14, 2020 • Revised: February 27, 2020 · Accepted: April 25, 2020 Corresponding author: Ali Reza Talebi

Department of Reproductive Biology, Yazd Reproductive Sciences Institute, Research and Clinical Center for Infertility, Shahid Sadoughi University of Medical Sciences, Bo-Ali Ave, Safayeh, Yazd 8916877391, Iran

Tel: +98-3531834234 Fax: +98-3531834234 E-mail: prof_talebi@hotmail.com

*The Yazd Reproductive Science Institute financially supported this study by purchasing all applied materials and animals.

This is an Open Access article distributed under the terms of the Creative Commons Attribution Non-Commercial License (http://creativecommons.org/licenses/by-nc/4.0/) which permits unrestricted non-commercial use, distribution, and reproduction in any medium, provided the original work is properly cited.

\section{Introduction}

Spermatogenesis is an essential process in the male reproductive system [1]. Associations of sex hormones with spermatogenesis, sperm survival, and DNA fragmentation have been demonstrated in previous research [2,3]. Sesame oil is an antioxidant agent containing large amounts of polyunsaturated fatty acids, lignin, and vitamin E. It has been proven that sesame oil can prevent DNA oxidative damage in an in vivo system [4]. The phytoestrogenic properties of sesame oil, similar to those of estradiol, may have additional effects on the improvement of sperm parameters and improve spermatogenesis through increasing epithelial proliferation and tubular thickening 
$[5,6]$. Aging has significant effects on sperm quality through the reduction of semen quality and an increase in DNA damage [7]. It has been observed that the increase in age has a detrimental effect on sperm DNA [8]. The production of reactive oxygen species (ROS) increases significantly in response to reduced production of steroidogenic enzymes. An increase in ROS also affects testicular morphology and reduces sperm parameters such as motility, concentration, and morphology $[9,10]$. These events may be associated with decreasing levels of estrogen and antioxidant agents associated with aging [11]. Estrogen affects the proliferation and arrangement of Sertoli cells, and it is also important for regulating the expression of the genes associated with cell adhesion $[3,9,12]$. The proteins that form adherent junctions include $\beta$-catenin and E-cadherin, which modulate intercellular junctions and stimulate hormones [13]. Furthermore, cadherins and catenins have effects on biological processes including intracellular messengers, signal transmission, and gene transcription. These actions may be associated with the regulatory function of steroids in reproductive tissues [14]. In addition, cadherins comprise a family of calcium-dependent glycoproteins that mediate cell-cell adhesion and sperm-oocyte interactions [15]. The presence of $\beta$-catenin is important for the adhesion of Sertoli cells, attachment to spermatids, and testicular-brain barrier function $[16,17]$. Many studies have been performed separately on the effect of sesame oil or estradiol on the testis; however, no study has yet compared the estrogenic effects of sesame or different concentrations of estradiol in old male mice. The aim of this study was to compare the estrogenic effects of sesame oil and different concentrations of estradiol on testicular structure, sperm parameters, chromatin/ DNA integrity, and expression of $E$-cadherin and $\beta$-catenin genes in old mouse testis.

\section{Methods}

The study was approved by the Animal Ethics Committee of the Yazd Reproductive Sciences Institute, Shahid Sadoughi University of Medical Sciences, Yazd, Iran (IR.SSU.RSI. REC.1394.5). All protocols were performed according to the National Institute of Health Guidelines for the Care and Use of Laboratory Animals (NIH Publications No. 8023, revised 1978).

\section{Sample collection}

Twenty old NMRI (The Naval Medical Research Institute) male mice (mean age, 40 weeks; weight, 30-35 g) were purchased from the Research and Clinical Center for Infertility, Shahid Sadoughi University of Medical Sciences, Yazd, Iran. All animals were kept in optimal housing and feeding conditions with a controlled temperature $\left(22^{\circ} \mathrm{C} \pm 2^{\circ} \mathrm{C}\right)$ and a 12 -hour light/dark cycle. The mice were divided into four groups ( $\mathrm{n}=5)$ : the E2-1 group ( $1 \mu \mathrm{L} / \mathrm{kg} /$ day of estradiol was intraperitoneally injected for 35 days), the E2-10 group (10 $\mu \mathrm{L} / \mathrm{kg} /$ day of estradiol was intraperitoneally injected for 35 days), the sesame oil group (10 $\mu \mathrm{L} / \mathrm{kg} /$ day of sesame oil was intraperitoneally injected for 35 days), and the control group (no treatment was done).

After 35 days (one cycle of spermatogenesis in mice), animals were sacrificed by cervical dislocation. The left cauda epididymis was removed and cut with a pair of syringes to transferred into Ham's F10 medium for the analysis of sperm parameters and DNA integrity. The left testicular tissue samples were used for the analysis of $E$-cadherin and $\beta$-catenin expression by molecular assays. To evaluate histological changes, the right testes were fixed in $4 \%$ paraformaldehyde solution.

\section{Sperm parameters}

After 30 minutes of incubation, sperm count, motility, and morphology were analyzed. A Makler chamber was used for the sperm count. Sperm motility was categorized as progressive, nonprogressive, and immotile spermatozoa. The percentage of sperm cells with normal morphology in the head, neck/mid-piece, and tail were obtained by Diff-Quik staining using light microscopy $(\times 1,000$ magnification) (Figure 1A) [18].

\section{Sperm chromatin integrity}

Aniline blue (AB) staining was applied to evaluate sperm chromatin integrity based on the residual histones in the chromatin structure. Briefly, slides were prepared by smearing, air-drying, and fixing a sperm sample. Then, the sample was incubated for 30 minutes in $3 \%$ glutaraldehyde in phosphate-buffered saline (PBS) at room temperature. The smears were stained in $5 \%$ aqueous $A B$ solution $(\mathrm{pH}$ 3.5) for 10 minutes. Afterward, the slides were rinsed and evaluated at $\times 1,000$ magnification. Immature and/or abnormal spermatozoa with additional histones were seen in dark blue and mature nuclei were detected as light blue (Figure 1B) [19].

\section{Sperm DNA fragmentation}

The percentage of sperm apoptosis was determined by terminal deoxynucleotidyl transferase dUTP nick end labeling (TUNEL) assay using a commercially available kit (In Situ Cell Death Detection Kit, fluorescein, Roche, USA). Spermatozoa with normal DNA show the background fluorescent color, while sperm with high DNA fragmentation has many $3-\mathrm{OH}$ ends, resulting in a strong fluorescent color. Firstly, the smears were fixed in methanol solution for 4 minutes. The slides were washed with PBS for 5 minutes three times. Later, they were incubated with blocking solution for $15-20$ minutes at $15^{\circ} \mathrm{C}-$ $25^{\circ} \mathrm{C}$ in a dark room. Samples were incubated with $0.1 \%(\mathrm{v} / \mathrm{v})$ Triton $\mathrm{X}-100$ containing $0.1 \%(\mathrm{w} / \mathrm{v})$ sodium citrate for 10 minutes on ice. 


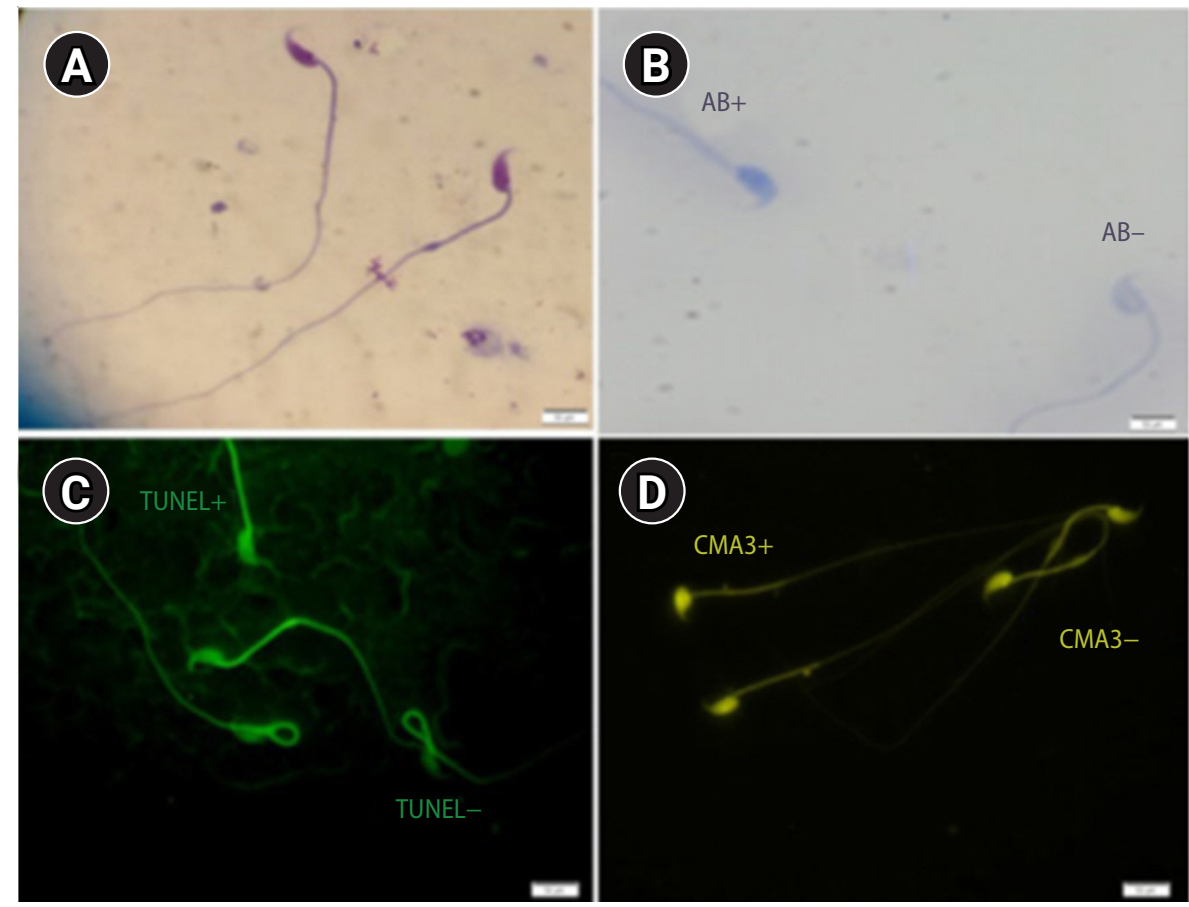

Figure 1. (A) Sperm morphology determined using Diff-Quik staining $(\times 1,000)$. (B) $A B$ staining assessing sperm chromatin status. Sperm heads with immature nuclear chromatin were shown as dark blue $(A B+)$ and those with mature nuclei $(A B-)$ were detected as light blue $(\times 1,000)$. (C) TUNEL assay: apoptosis-positive cells are brilliant fluorescent green (TUNEL+) and apoptosis-negative cells are pale and opaque green (TUNEL-) (×1,000). (D) CMA3-positive cells $(C M A 3+)$ were seen as bright yellow, whereas cells with no protamine defects stained dark yellow (CMA3-) ( $\times 1,000)$. AB, aniline blue; TUNEL, terminal deoxynucleotidyl transferase dUTP nick end labeling; CMA3, chromomycin $A 3$.

Slides were again washed three times with PBS for 5 minutes and were stained with $50 \mu \mathrm{L}$ of TUNEL reaction mixture for 1 hour at $37^{\circ} \mathrm{C}$ in a dark and humidified atmosphere. Then, they were examined under a fluorescent microscope at $\times 1,000$ magnification (BX51; Olympus, Tokyo, Japan) (Figure 1C) [20].

\section{Sperm protamine deficiency}

Protamine deficiency in sperm was analyzed by chromomycin A3 (CMA3), which is bright yellow. The smears were fixed immediately with Carnoy solution for 10 minutes at $4^{\circ} \mathrm{C}$. Each slide was treated with $100 \mu \mathrm{L}$ of CMA3 solution for 10 minutes in a dark room (Sigma-Aldrich, St. Louis, MO, USA). The slides were rinsed in Mclrvin buffer and air-dried. The slides were analyzed using fluorescent microscopy with suitable filters $(\times 1,000$ magnification) (Figure 1D) [20].

\section{Gene expression}

The testis tissue of each mouse was used for RNA extraction. Total RNA was extracted by the QuantiTect, RNeasy Micro kit (Qiagen, Hilden, Germany), following a slight modification of the manufacturer's protocol in a total volume of $14 \mu \mathrm{L}$. Concentrations of extracted RNA were measured by a Nanodrop spectrophotometer (Thermo
Scientific, Waltham, MA, USA). Subsequently, 1,000 ng/ $\mu \mathrm{L}$ of extracted total RNA was reverse-transcribed using the Revert Aid First Strand cDNA synthesis kit (Thermo Fisher Scientific Inc., Waltham, MA, USA) according to the manufacturer's instructions. For negative control samples, the reverse transcriptase enzyme or the RNA template was removed from the reactions. Synthetic cDNA was stored at $-80^{\circ} \mathrm{C}$ until quantitative real-time polymerase chain reaction was performed to assess the relative gene expression levels of the genes encoding $E$-cadherin and $\beta$-catenin in testis tissue from all groups, and the $\beta$-actin gene was considered as a reference gene for normalization. Relative expression of the genes was calculated using the QuantiTect SYBER Green RT-PCR kit (Applied Biosystems, Foster City, CA, USA) by an RT-PCR thermocycler (ABI 7500 Step One, Applied Biosystems). Primer sequences for genes are listed in Table 1. Amplification of all runs was performed in duplicate by an expert laboratory assistant blinded to the study design.

\section{Testicular histology}

Testicular sections were prepared with a $5-\mu \mathrm{m}$ thickness. Furthermore, hematoxylin and eosin staining was performed to analyze the diameter of seminiferous tubules using an optical microscope (BX51, Olympus). In each section, three fields and at least 20 tubules were 
randomly selected. In this regard, large and small diameters were measured in each tubule and the average diameter was recorded. The thickness of the germinal epithelium layer was also calculated by subtracting the inner diameter of the tubule from the overall diameter of the seminiferous tubule [21]. Sertoli cells, spermatogonia, primary spermatocytes, spermatids, and Leydig cells were counted in each testis.

\section{Statistical analysis}

One-way analysis of variance was used to compare the data and Pearson correlation coefficients were used to quantify the relationships between the variables, with $p$-values $<0.05$ considered to indicate statistical significance. The data were analyzed using IBM SPSS ver. 20 (IBM Corp., Armonk, NY, USA) and GraphPad software (GraphPad Inc., La Jolla, CA, USA) was used to draw the charts.

\section{Results}

As shown in Table 2, the percentage of progressive motility was significantly lower in the E2-10 group than in the control group $(p<0.05)$. There was no significant difference in the proportion of nonprogressive sperm across all groups. The percentage of immotile sperm was higher in the E2-10 and sesame oil groups than in the control group $(p<0.05)$. Normal morphology (Figure 1A) was significantly lower in the E2-10 group than in the control group $(p<0.05)$ (Table 2). The rate of abnormal chromatin in AB staining in the E2-10 and sesame oil groups was higher than in the control group and the low-dose estradiol group ( $p<0.001$ ) (Table 2, Figure 1B). As shown in Table 2, a difference was observed between the E2-10 and control groups in the TUNEL assay $(p<0.05)$ (Figure $1 C)$. The results of CMA3 staining showed higher percentages of abnormal sperm in the E2-10 and sesame oil groups than in the control group $(p<0.001)$ (Table 2 , Figure 1D). The expression of $\beta$-catenin and $E$-catenin was quantified in all groups (Table 1). The relative expression of $\beta$-catenin mRNA in the E2-1 ( $p=0.002)$ and E2-10 ( $p=0.012)$ groups was higher than in the control group (Figure $2 \mathrm{~A}$ ), but the relative expression of $E$-catenin mRNA did not significantly differ across all groups (Figure 2B). The number of spermatogonia showed no significant difference in any group compared to the control group (Figure 3A). The E2-10 group displayed higher primary spermatocyte, spermatid cell, and Sertoli cell counts compared to the controls at 35 days $(p<0.05)$ (Figure 3BD). The Leydig cell count was significantly higher in the E2-1 and E210 groups ( $p<0.001$ ) (Figure 3E). In the E2-10 group (Figure 4A), the lumen diameter was significantly lower than that of the control animals $(p<0.05)$, and the cellular diameters of the seminiferous tubules were also significantly higher in the E2-1 $(p<0.05)$ and E2-10

Table 1. The primers used in real-time PCR

\begin{tabular}{lllc}
\hline Accession number & Gene & \multicolumn{1}{c}{ Primer sequence (5'-3') } & PCR product (bp) \\
\hline NM_009864.3 & E-cadherin & F: AGCCATTGCCAAGTACATCC & 133 \\
NM_001165902.1 & & R: AAAGACCGGCTGGGTAAACT & 166 \\
NM_007393.5 & $\beta$-catenin & F:TCCCATCCACGCAGTTGAC & 144 \\
& & R:TCCTCATCGTTTAGCAGTTTTG & \\
\hline
\end{tabular}

$P C R$, polymerase chain reaction; $F$, forward; $R$, reverse.

Table 2. Comparison sperm parameters and sperm function tests between control and experimental groups

\begin{tabular}{lcccc}
\hline Variable & Control & E2-1 & E2-10 & Sesame oil \\
\hline Sperm count $\left(\times 10^{6} / \mathrm{mL}\right)$ & $27.8 \pm 1$ & $10.8 \pm 1$ & $2.6 \pm 1$ & $11 \pm 1$ \\
Progressive motility (\%) & $41 \pm 20$ & $54.2 \pm 1$ & $15 \pm 8$ & $30.2 \pm 1$ \\
Non-progressive motility (\%) & $29 \pm 9$ & $17 \pm 6$ & $80 \pm 14^{\text {b) }}$ & $12 \pm 5$ \\
Immotile (\%) & $34 \pm 14$ & $33.8 \pm 12$ & $30 \pm 0^{\text {a) }}$ & $62.2 \pm 24$ \\
Normal morphology (\%) & $57 \pm 3$ & $57 \pm 16$ & $34 \pm 5^{\text {b) }}$ & $42 \pm 6$ \\
AB (\%) & $19 \pm 3$ & $33 \pm 3^{\text {b) }}$ & $22 \pm 13$ & $33 \pm 6^{\text {b) }}$ \\
TUNEL assay (\%) & $11 \pm 2$ & $10 \pm 2$ & $29 \pm 2$ & $15 \pm 2$ \\
CMA3 (\%) & $20 \pm 1$ & $22 \pm 3$ & $28 \pm 11$ \\
\hline
\end{tabular}

Values are presented as mean \pm standard deviation. The E2-1, E2-10 and sesame oil group were intraperitoneally injected with $1 \mu \mathrm{L} / \mathrm{kg} / \mathrm{day}$ of estradiol, $10 \mu \mathrm{L} /$ $\mathrm{kg} /$ day of estradiol, and $10 \mu \mathrm{L} / \mathrm{kg} /$ day of sesame oil for 35 days, respectively.

$\mathrm{AB}$, aniline blue; TUNEL, terminal deoxynucleotidyl transferase dUTP nick end labeling; CMA3, chromomycin A3.

Compared to the control group: ${ }^{\text {a) }} p<0.05,{ }^{\text {b) }} p<0.001$. 

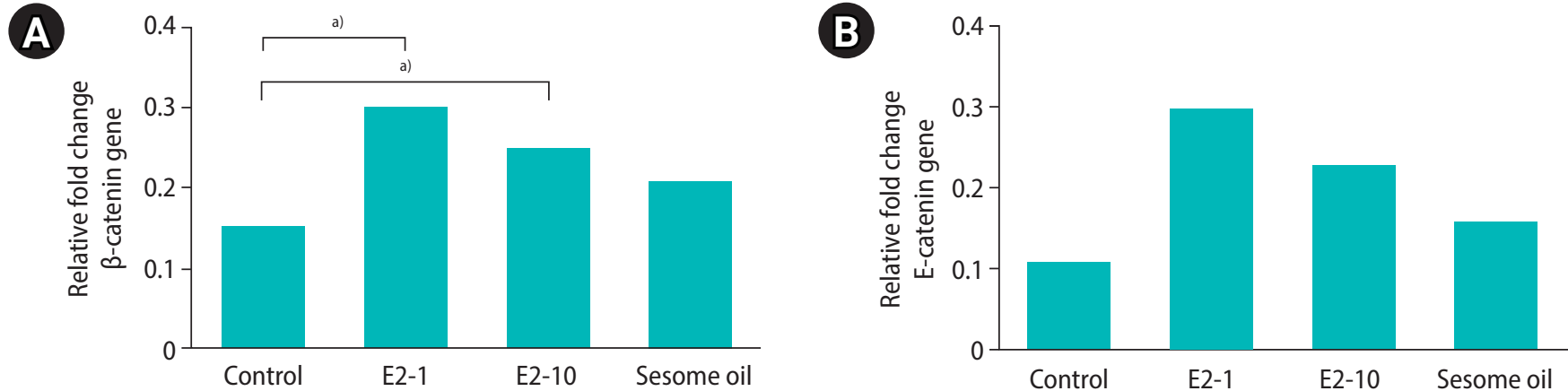

Figure 2. (A) Evaluation of mRNA levels of the $\beta$-catenin gene. (B) Evaluation of mRNA levels of the E-cadherin gene. The E2-1, E2-10 and sesame oil group were intraperitoneally injected with $1 \mu \mathrm{L} / \mathrm{kg} /$ day of estradiol, $10 \mu \mathrm{L} / \mathrm{kg} /$ day of estradiol, and $10 \mu \mathrm{L} / \mathrm{kg} /$ day of sesame oil for 35 days, respectively. ${ }^{a}$ Significant mRNA levels of $\beta$-catenin and $E$-cadherin $(p<0.05)$ when compared to the control group.

A

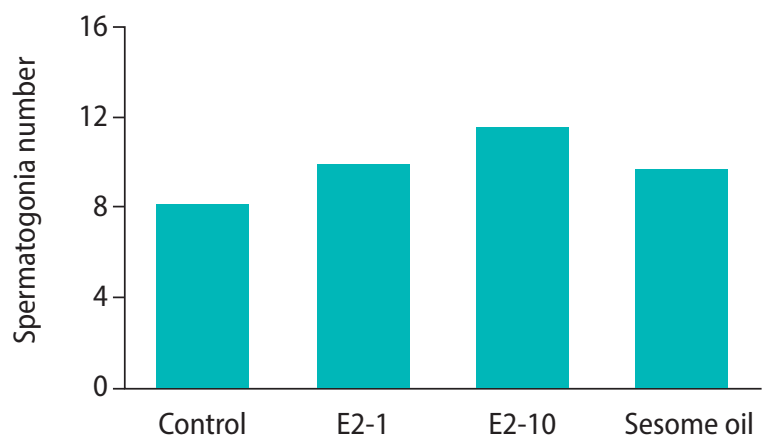

C

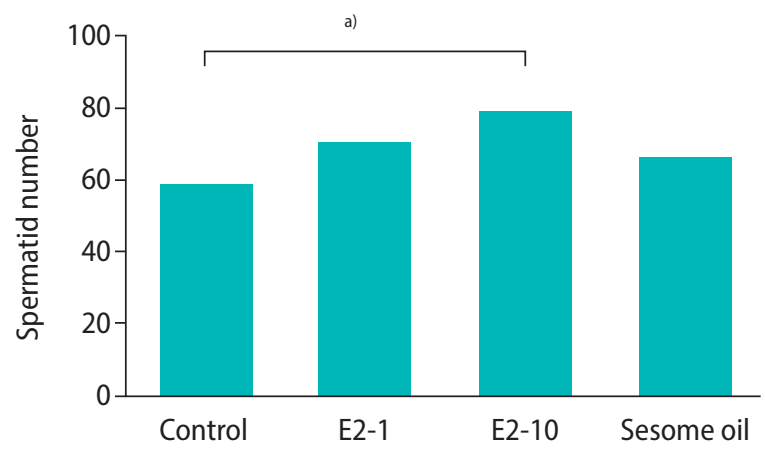

E

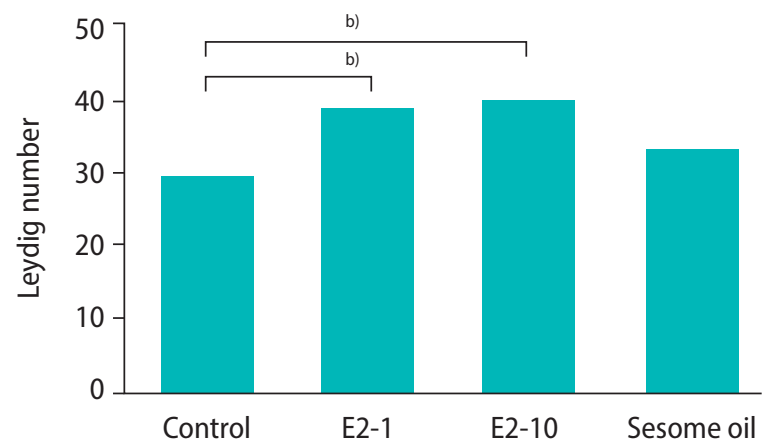

B

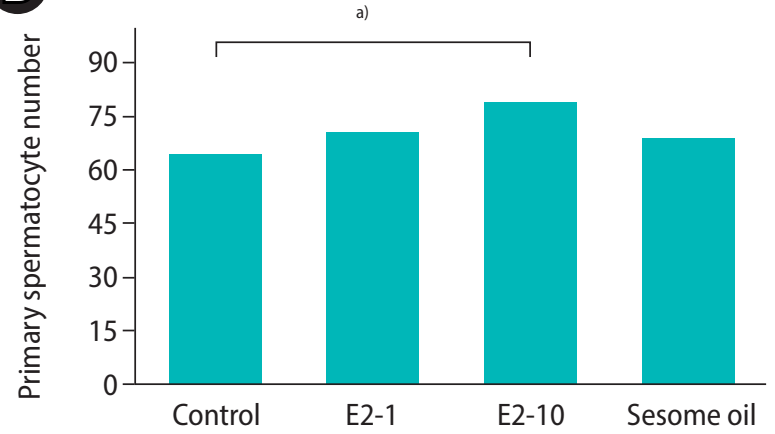

D

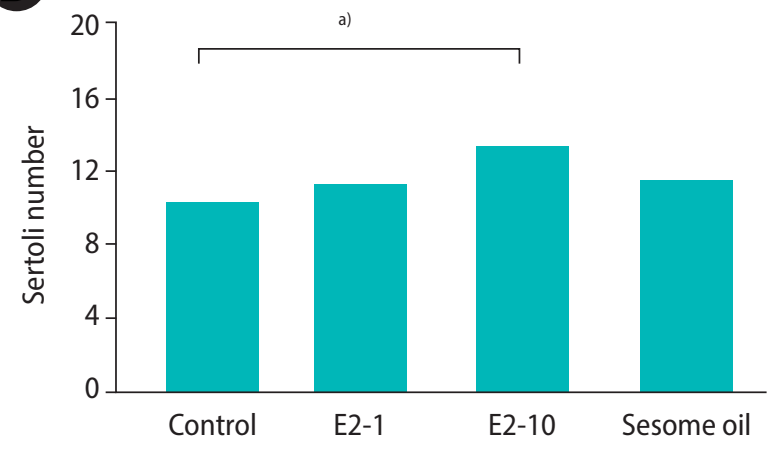

Figure 3. Mean and standard error of cell counts in seminiferous tubules in the E2-1, E2-10, and sesame oil groups, which were intraperitoneally injected with $1 \mu \mathrm{L} / \mathrm{kg} /$ day of estradiol, $10 \mu \mathrm{L} / \mathrm{kg} /$ day of estradiol, and $10 \mu \mathrm{L} / \mathrm{kg} /$ day of sesame oil for 35 days, respectively. (A) Spermatogonia cell count, (B) primary spermatocyte cell count, (C) spermatid cell count, (D) Sertoli cell count, (E) Leydig cell count. Significant differences between groups: ${ }^{\mathrm{a}} p<0.05,{ }^{\text {b) }} p<0.001$. 

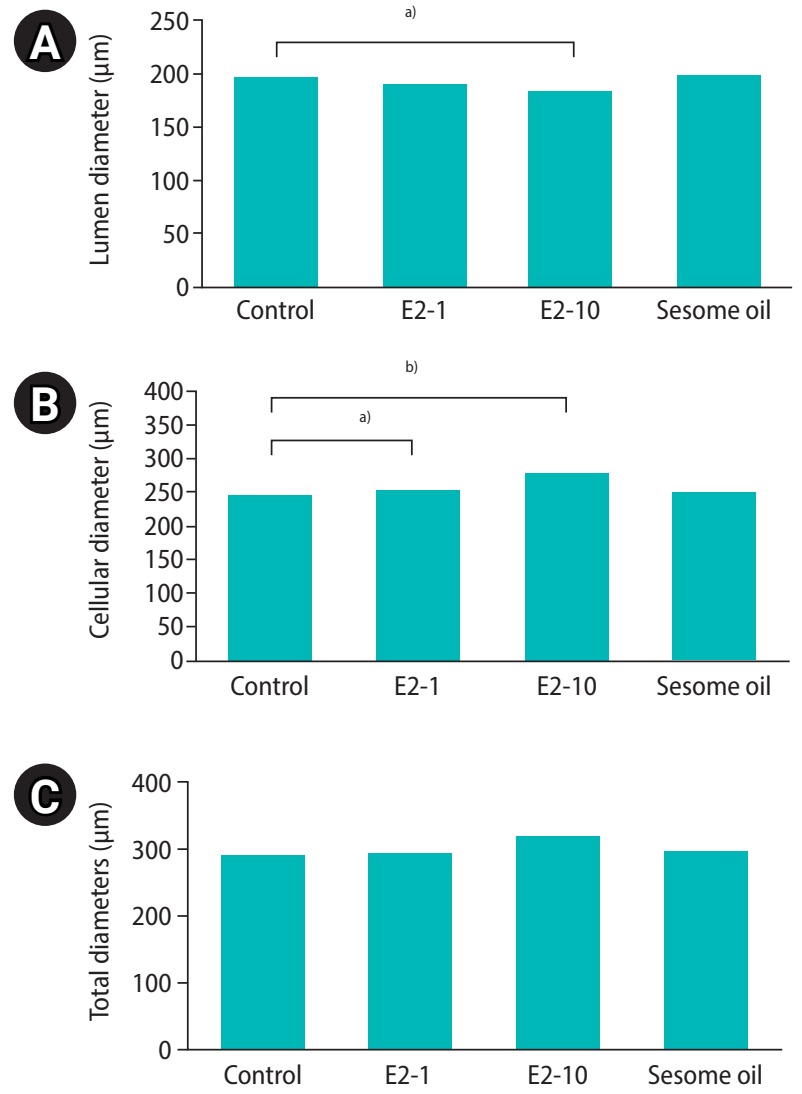

Figure 4. Mean and standard error of stereological indices of seminiferous tubules in the E2-1, E2-10, and sesame oil groups, which were intraperitoneally injected with $1 \mu \mathrm{L} / \mathrm{kg} /$ day of estradiol, $10 \mu \mathrm{L} / \mathrm{kg} /$ day of estradiol, and $10 \mu \mathrm{L} / \mathrm{kg} /$ day of sesame oil for 35 days, respectively. (A) Lumen diameter $(\mu \mathrm{m}),(B)$ cellular diameter $(\mu \mathrm{m}),(\mathrm{C})$ total diameters $(\mu \mathrm{m})$ of the tubule. Significant differences between groups: ${ }^{\mathrm{a})} p<0.05,{ }^{\mathrm{b})} p<0.001$.

$(p<0.05)$ groups (Figure 4B). The total diameter did not significantly vary across all groups (Figure 4 C).

\section{Discussion}

Spermatogenesis decreases daily with a rate of $30 \%$ in men above 50 years old [22-24], and aging affects sperm parameters such as sperm motility and viability, as well as sperm chromatin status. Sesame oil is important source of phytoestrogens and has estrogenic properties [25]; furthermore, it can improve sperm count and motility. Thus, it has been suggested that sesame oil could be considered as an effective agent for improving the condition of epididymal spermatozoa [26]. An appropriate dose of sesame oil for its high antioxidant activity may have effective anti-aging results due to its ability to neutralize physiological ROS. Increased ROS levels in semen cause sperm dysfunction and DNA damage by oxidative stress, accounting for $25 \%$ of cases of induced male infertility $[27,28]$. This study showed that sesame oil was more effective than estradiol at $10 \mu \mathrm{L} /$ $\mathrm{kg}$ in improving sperm parameters such as progressive motility and morphology. The more favorable effects of sesame oil may be due to its antioxidant properties and ability to bind to antioxidant enzymes within the cell [29]. In contrast, Abbasi et al. [30] reported that sesame oil could improve sperm parameters in diabetic rats, potentially due to hormonal imbalance and the presence of abundant ROS in those animals. Lubbert et al. [31] reported that a high dose $(60 \mu \mathrm{g} /$ day) of estrogen and a long duration of treatment could impact sperm motility and count [9]. Our results demonstrated the effects of an injection of $1 \mu \mathrm{L} / \mathrm{kg} /$ day of estradiol on sperm motility. In addition, we observed that a higher concentration of estradiol $(10 \mu \mathrm{L} / \mathrm{kg} /$ day of estradiol) had a negative effect on sperm motility, but did increase the sperm count. Lubbert et al. [31] found that although a high dose of estrogen ( $60 \mu \mathrm{g} /$ day) reduced the sperm count, low doses $(20 \mu \mathrm{g} /$ day $)$ did not have a negative effect on the sperm count in adult men. The effect of a high dose of estrogen on the sperm count was observed a few days after injection. Steroid hormones play vitally important roles in the maintenance of male reproductive function [32]. and sperm DNA fragmentation and progressive motility are important factors for the evaluation of fertility [33-35]. Based on our data, a low dose of estradiol may lead to improvement in sperm parameters, especially chromatin quality and DNA fragmentation, rather than a high dose of estradiol. In this study, CMA3, TUNEL, and $A B$ assays were used to evaluate chromatin and DNA status. The results of CMA3, TUNEL, and AB tests showed that low concentrations of estradiol and sesame oil were more appropriate than higher concentrations of estradiol. In another study, Ebrahimi et al. [36] detected that sesame oil had anti-apoptotic effects on sperm. Our data showed that $1 \mu \mathrm{L} / \mathrm{kg} /$ day of estradiol led to the most favorable results in the TUNEL assay. The CMA3 assay is a suitable method for detecting protamine deficiency in sperm chromatin [37-40]. Although a few studies have been conducted on the effect of estrogen on the gene expression of Sertoli-spermatid binding proteins [17], to the best of our knowledge, no study has reported the effects of different exogenous estrogen doses on the expression of $E$-cadherin and $\beta$-catenin. Our study showed that a low concentration of estradiol downregulated the $\beta$-catenin gene, which plays a role in germ cell-to-Sertoli cell attachment and mediates proteins in cellular connections, but there was no effect on the expression of the gene coding for E-cadherin, which also plays an important structural role [41]. A higher dose of estradiol ( $10 \mu \mathrm{L} / \mathrm{kg} /$ day) improved spermatogenesis in mice. This finding was confirmed by a significantly higher number of spermatogonia cells in the animals that received $10 \mu \mathrm{L} / \mathrm{kg} /$ day of estradiol than was found in the control group. Furthermore, the numbers of primary spermatocytes, spermatids, Sertoli cells, and Leydig cells were significantly higher in the E2-10 group than in the 
control group. Toyama et al. [42] studied six different doses of estradiol and they reported that the effects of estradiol on the male reproductive system were dose-dependent [43]. It has also been found that estradiol synthesis by seminiferous cells plays an important role in tubal hormonal regulation and spermatogenesis improvement. and estradiol and platelet-derived growth factor likely induce proliferation of seminiferous cells in both a dose-dependent and dose-insensitive manner [44]. Moreover, incubation of the seminiferous tubules with estradiol inhibits apoptosis and produces germ cells in these tubules. Therefore, estradiol is a very important hormone for the survival of germ cells [45]. In addition, the estradiol beta receptor is present in Sertoli cells and estradiol exerts its effects through this receptor [46]. Our results showed an a higher cellular diameter of seminiferous tubules in mice that received $10 \mu \mathrm{L} / \mathrm{kg} /$ day of estradiol than was found in the control group. Moreover, MacCalman et al. [47] showed that estradiol increased the stimulating effects of follicle-stimulating hormone (FSH) and N-cadherin (a protein that is essential for adhesion and internal cell adhesion in the seminal epithelium) mRNA levels. The interaction between FSH and estradiol in Sertoli cells stimulates the mitotic activity of these cells [48-50]. Therefore, the increase of the cellular diameter was probably due to the interaction of injected estradiol with FSH. Furthermore, changes in tubal diameter could occur due to an increase in the number of germ lineage cells within the seminiferous tubules [51]. According to Shittu et al. [52], sesame oil raises testosterone levels and testosterone increases spermatogenesis in male animals. The aqueous extract of sesame leaves has an antioxidant effect and significantly increases the number of spermatogonia, seminiferous tubules, and testosterone levels. According to other researchers, sesame phytoestrogens bind to testicular estrogen receptors and stimulate spermatogenesis through the proliferation of epithelial cells and sex cells $[52,53]$. In the sesame oil and high-dose estradiol groups, a higher rate of chromatin and DNA damage was observed than in the control group and the low-dose estradiol group. Low doses of estradiol had a greater effect on sperm motility, in addition to exerting less chromatin and DNA damage. Therefore, it is recommended to use a combination of a low dose of estradiol and sesame oil. This combination may lead to a reduction of age-related ROS by balancing the oxidants and antioxidants in the cell. These are novel findings.

Despite the beneficial effects of high-dose estradiol on testicular function, we recommend that low doses of estradiol or sesame oil may play an important role on optimizing sperm parameters and chromatin quality in older mice.

\section{Conflict of interest}

No potential conflict of interest relevant to this article was reported.

\section{Acknowledgments}

The authors would like to thank Yazd Reproductive Science Institute for financial support of the current study.

\section{ORCID}

MasoomehMohammadzadeh https://orcid.org/0000-0003-2245-4700

Majid Pourentezari https://orcid.org/0000-0001-7549-4672

Hadi Zare-Zardini https://orcid.org/0000-0002-1501-2560

Ali Nabi https://orcid.org/0000-0002-3794-6073

Saeed Ghasemi Esmailabad https://orcid.org/0000-0002-9652-8699

Ali Khodadadian

Ali Reza Talebi

https://orcid.org/0000-0001-9192-2016

https://orcid.org/0000-0001-7753-0710

\section{Author contributions}

Conceptualization: ART, HZZ. Funding acquisition: MM, MP. Methodology: MM, ART. Project administration: AN, SGE. Writing-original draft: ART. Writing-review \& editing: AK.

\section{References}

1. Walker WH, Cheng J. FSH and testosterone signaling in Sertoli cells. Reproduction 2005;130:15-28.

2. O'Donnell L, Robertson KM, Jones ME, Simpson ER. Estrogen and spermatogenesis. Endocr Rev 2001;22:289-318.

3. Leavy M, Trottmann M, Liedl B, Reese S, Stief C, Freitag B, et al. Effects of elevated $\beta$-estradiol levels on the functional morphology of the testis: new insights. Sci Rep 2017;7:39931.

4. Khaneshi F, Nasrolahi O, Azizi S, Nejati V. Sesame effects on testicular damage in streptozotocin-induced diabetes rats. Avicenna J Phytomed 2013;3:347-55.

5. Shittu LA, Shittu RK, Olufemi O, Tayo AO, Osunubi AA. Hypoglycaemia and improved testicular parameters in Sesamum radiatum treated normo-glycaemic adult male Sprague Dawley rats. Afr J Biotechnol 2009;8:2878-86.

6. National Research Council of the National Academies. Guide for the care and use of laboratory animals. Washington: The National Academies Press; 2010.

7. Almeida S, Rato L, Sousa M, Alves MG, Oliveira PF. Fertility and sperm quality in the aging male. Curr Pharm Des 2017;23:4429_ 
37.

8. Alshahrani S, Agarwal A, Assidi M, Abuzenadah AM, Durairajanayagam D, Ayaz A, et al. Infertile men older than 40 years are at higher risk of sperm DNA damage. Reprod Biol Endocrinol 2014; $12: 103$.

9. Dostalova P, Zatecka E, Dvorakova-Hortova K. Of oestrogens and sperm: areview of the roles of oestrogens and oestrogen receptors in male reproduction. Int J Mol Sci 2017;18:904.

10. Huang J, Chen L, Wan L, Yang JG, Wang H, Zhou XY, et al. An analysis of donor semen quality in Chongqing Human Sperm Bank. Zhonghua Nan Ke Xue 2018;24:700-4.

11. Ge ZJ, Schatten H, Zhang CL, Sun QY. Oocyte ageing and epigenetics. Reproduction 2015;149:R103-14.

12. Hirakawa I, Miyagawa S, Katsu Y, Kagami Y, Tatarazako N, Kobayashi T, et al. Gene expression profiles in the testis associated with testis-ova in adult Japanese medaka (Oryziaslatipes) exposed to 17a-ethinylestradiol. Chemosphere 2012;87:668-74.

13. Yamada S, Pokutta S, Drees F, Weis WI, Nelson WJ. Deconstructing the cadherin-catenin-actin complex. Cell 2005;123:889-901.

14. Rowlands TM, Symonds JM, Farookhi R, Blaschuk OW. Cadherins: crucial regulators of structure and function in reproductive tissues. Rev Reprod 2000;5:53-61.

15. Purohit S, Brahmaraju M, Palta A, Shukla S, Laloraya M, Kumar PG. Impaired E-cadherin expression in human spermatozoa in a male factor infertility subset signifies E-cadherin-mediated adhesion mechanisms operative in sperm-oolemma interactions. Biochem Biophys Res Commun 2004;316:903-9.

16. Tsuchiya B, Sato Y, Kameya T, Okayasu I, Mukai K. Differential expression of $\mathrm{N}$-cadherin and $\mathrm{E}$-cadherin in normal human tissues. Arch Histol Cytol 2006;69:135-45.

17. Ha HK, Park HJ, Park NC. Expression of E-cadherin and a-catenin in a varicocele-induced infertility rat model. Asian J Androl 2011; 13:470-5.

18. Bandegi L, Anvari M, Vakili M, Khoradmehr A, Mirjalili A, Talebi AR. Effects of antidepressants on parameters, melondiadehyde, and diphenyl-2-picryl-hydrazyl levels in mice spermatozoa. Int J Reprod Biomed 2018;16:365-72.

19. Pourmasumi S, Khoradmehr A, Rahiminia T, Sabeti P, Talebi AR, Ghasemzadeh J. Evaluation of sperm chromatin integrity using aniline blue and toluidine blue staining in infertile and normozoospermic men. J Reprod Infertil 2019;20:95-101.

20. Nazar M, Talebi AR, Hosseini Sharifabad M, Abbasi A, Khoradmehr A, Danafar AH. Acute and chronic effects of gold nanoparticles on sperm parameters and chromatin structure in Mice. Int J Reprod Biomed 2016;14:637-42.

21. Costa DS, Paula TA, Matta SL. The intertubular compartment morphometry in capybaras (Hydrochoerus hydrochaeris) testis. Anim
Reprod Sci 2006;91:173-9.

22. Stone BA, Alex A, Werlin LB, Marrs RP. Age thresholds for changes in semen parameters in men. Fertil Steril 2013;100:952-8.

23. Kumar N, Singh AK, Choudhari AR. Impact of age on semen parameters in male partners of infertile couples in a rural tertiary care center of central India: a cross-sectional study. Int J Reprod Biomed 2017;15:497-502.

24. Levitas E, Lunenfeld E, Weisz N, Friger M, Potashnik G. Relationship between age and semen parameters in men with normal sperm concentration: analysis of 6022 semen samples. Andrologia 2007;39:45-50.

25. Ryan E, Galvin K, O'Connor TP, Maguire AR, O'Brien NM. Phytosterol, squalene, tocopherol content and fatty acid profile of selected seeds, grains, and legumes. Plant Foods Hum Nutr 2007;62:8591.

26. Khani B, Bidgoli SR, Moattar F, Hassani H. Effect of sesame on sperm quality of infertile men. J Res Med Sci 2013;18:184-7.

27. Agarwal A, Nallella KP, Allamaneni SS, Said TM. Role of antioxidants in treatment of male infertility: an overview of the literature. Reprod Biomed Online 2004;8:616-27.

28. Patel SR, Sigman M. Antioxidant therapy in male infertility. Urol Clin North Am 2008;35:319-30.

29. Jeng KC, Hou RC. Sesamin and sesamolin: nature's therapeutic lignans. Curr Enzym Inhib 2005;1:11-20.

30. Abbasi Z, Tabatabaei SR, Mazaheri Y, Barati F, Morovvati H. Effects of sesame oil on the reproductive parameters of diabetes mellitus-induced male rats. World J Mens Health 2013;31:141-9.

31. Lubbert H, Leo-Rossberg I, Hammerstein J. Effects of ethinyl estradiol on semen quality and various hormonal parameters in a eugonadal male. Fertil Steril 1992;58:603-8.

32. Patrao MT, Silva EJ, Avellar MC. Androgens and the male reproductive tract: an overview of classical roles and current perspectives. Arq Bras Endocrinol Metabol 2009;53:934-45.

33. Belloc S, Hazout A, Zini A, Merviel P, Cabry R, Chahine H, et al. How to overcome male infertility after 40: influence of paternal age on fertility. Maturitas 2014;78:22-9.

34. Mirzazadeh M, Sadri-Ardekani H. Implications of ejaculatory sperm DNA fragmentation on male infertility management. Transl Androl Urol 2017;6(Suppl 4):S402-4.

35. Cho CL, Agarwal A. Role of sperm DNA fragmentation in male factor infertility: a systematic review. Arab J Urol 2017;16:21-34.

36. Ebrahimi M, Dehghani F, Farhadian N, Karimi M, Golmohammadzadeh S. Investigating the anti-apoptotic effect of sesame oil and honey in a novel nanostructure form for treatment of heart failure. Nanomed J 2017;4:245-53.

37. Bianchi PG, Manicardi GC, Urner F, Campana A, Sakkas D. Chromatin packaging and morphology in ejaculated human spermato- 
zoa: evidence of hidden anomalies in normal spermatozoa. Mol Hum Reprod 1996;2:139-44.

38. Balhorn R, Reed S, Tanphaichitr N. Aberrant protamine 1/protamine 2 ratios in sperm of infertile human males. Experientia 1988;44:52-5.

39. Bianchi PG, Manicardi GC, Bizzaro D, Bianchi U, Sakkas D. Effect of deoxyribonucleic acid protamination on fluorochrome staining and in situ nick-translation of murine and human mature spermatozoa. Biol Reprod 1993;49:1083-8.

40. Iranpour FG. The effects of protamine deficiency on ultrastructure of human sperm nucleus. Adv Biomed Res 2014;3:24.

41. Weider K, Bergmann M, Brehm R. Connexin 43: its regulatory role in testicular junction dynamics and spermatogenesis. Histol Histopathol 2011;26:1343-52.

42. Toyama Y, Hosoi I, Ichikawa S, Maruoka M, Yashiro E, Ito H, et al. Beta-estradiol 3-benzoate affects spermatogenesis in the adult mouse. Mol Cell Endocrinol 2001;178:161-8.

43. Nakamura N, Sloper DT, Del Valle PL. Evaluation of an in vitro mouse testis organ culture system for assessing male reproductive toxicity. Birth Defects Res 2019;111:70-7

44. Senarat S, Kettratad J, Jiraungkoorskul W, Plumley FG, Tongmit K, Poolprasert $\mathrm{P}$, et al. Identification of sbGnRH-GTHs system and estrogen receptor a (ER a) immunoreactivities in the mature testicular tissue in Rastrelliger brachysoma (Bleeker, 1851). Eurasia J Biosci 2018;12:385-92.

45. Pentikainen V, Erkkila K, Suomalainen L, Parvinen M, Dunkel L. Estradiol acts as a germ cell survival factor in the human testis in vitro. J Clin Endocrinol Metab 2000;85:2057-67.
46. Lambard S, Carreau S. Aromatase and oestrogens in human male germ cells. Int J Androl 2005;28:254-9.

47. MacCalman CD, Getsios S, Farookhi R, Blaschuk OW. Estrogens potentiate the stimulatory effects of follicle-stimulating hormone on $\mathrm{N}$-cadherin messenger ribonucleic acid levels in cultured mouse Sertoli cells. Endocrinology 1997;138:41-8.

48. Dorrington JH, Bendell JJ, Khan SA. Interactions between FSH, estradiol-17 beta and transforming growth factor-beta regulate growth and differentiation in the rat gonad. J Steroid Biochem Mol Biol 1993;44:441-7.

49. Lucas TF, Lazari MF, Porto CS. Differential role of the estrogen receptors ESR1 and ESR2 on the regulation of proteins involved with proliferation and differentiation of Sertoli cells from 15-dayold rats. Mol Cell Endocrinol 2014;382:84-96.

50. Royer C, Lucas TF, Lazari MF, Porto CS. 17Beta-estradiol signaling and regulation of proliferation and apoptosis of rat Sertoli cells. Biol Reprod 2012;86:108.

51. Sperling MA. Pediatric endocrinolog. Amsterdam: Elsevier Health Sciences; 2014.

52. Shittu LA, Shittu RK, Osinubi AA, Ashiru OA. Stereological evidences of epithelial hypoplasia of Seminiferous tubules induced by mesterolone in adult Sprague-Dawley rats. Afr J Endocrinol Metab 2008;7:14-7.

53. Oluyemi KA, Jimoh OR, Adesanya OA, Omotuyi IO, Josiah SJ, Oyesola TO. Effects of crude ethanolic extract of Garcinia cambogia on the reproductive system of male wistar rats (Rattus novergicus). Afr J Biotechnol 2007;6:1236-8. 